\title{
KUN ET SKELET TILBAGE \\ Objektivering, tid og sex et sted i Nordøstbrasilien
}

\author{
ANNE LINE DALSGAARD
}

Hvis mennesket lever vendt imod det, som endnu vil komme, mod potentialet, som endnu skal forløses, sådan som Heidegger (1927) og andre skriver, hvordan håndterer man da endelighedens konkrete manifestation? Hvis oplevelsen af at være „nogen“ $i$ andres øjne bekræfter vores eksistens og tillader os at udskyde tanken om, at den må ophøre, hvordan stiller man sig da over for det faktum, at man i samfundsperspektiv er uden værdi? Som når et skelet ser på en, som fremtiden ser på nutiden, og adresserer den uro, man inderst inde føler ved tanken om absolut udslettelse? Denne artikel vil ikke besvare disse spørgsmål, dertil er de for store og absolutte. Artiklen vil blot foreslå et svar, som knytter sig til en specifik lokal person, en ung kvinde, i en specifik lokal situation. Kvinden hedder Evinha, hun er 30 år, mor til en søn på 10 og bosat i et fattigt bykvarter i udkanten af Recife i Nordøstbrasilien. Hun tilhører med stor sandsynlighed den kategori af brasilianere, som ikke sætter sig materielle spor. Ikke alene ejer de intet af værdi, deres materielle krop vil efter døden ikke blive lagt til hvile i en navngiven grav, men vil snart forsvinde i anonymitet. I det følgende vil jeg foreslå en mulig sammenhæng mellem Evinhas vished om dette og hendes ofte ganske letsindige forhold til seksuel objektivering

\section{Evinha}

Solen er hård den eftermiddag. Hun står sammen med alle de andre fra kvarteret, fastholdt af synet af den sammenkrøbne krop. Morderne var kommet natten før, med hætter over hovederne, havde sparket døren ind og trukket ham udenfor, mens hans kone og mor skreg, og børnene så til. De skød ham, mens han krøb sammen op ad muren. Kvinderne skreg længe efter, men ingen turde gå ud. Nu er der fluer i hans sår, og blodet, som er løbet ned ad hans kind, er brunt og skor- 
pet. Han har ligget sådan, siden de skød ham, for ingen tør røre ham, før politiet kommer. Stilstanden er ulidelig.

\section{En ung kvinde}

Hun kan lide at se på sig selv i spejlet. Det ene bryst er blevet større end det andet af amningen. Hun har vasket tøj hele dagen, håret er kruset og bør glattes ud, neglelakken knækket, men numsen er god. Hun spiller Whitney Houston, titelnummeret fra Bodyguard, og synger med. Hun er flyttet fra fyren med de grønne øjne, flyttet fra hans druk, fra slagene, som faldt så beregneligt, når han igen kom sent hjem. Flyttet fra gryderne, som skulle vaskes, fra pengene, som ikke slog til, og madrassen, som var gammel og lugtede. Fra alt det, som var hendes liv. Hjem til bedstemor. Hvad skal der blive af hende og barnet? Hun skruer højere op for musikken. Udenfor løber nogen forbi og råber.

\section{Sex}

Hun begærer barnets far, vil være hans, vil tages af ham, mærke sveden imellem dem, når han ligger over hende. Der er ikke noget, hun hellere vil, det gør ondt i kødet, trækker og slider. Hun må ud at gå i gaderne, bare gå og gå, mærke muligheden af hans øjne på sig. Barnet skriger, og hun har lyst til at slå. Hun får bedstemor til at passe barnet og går ud. Der er ikke mange ude. Inde i husene er folk ved at være parate til natten, flere steder er mændene hjemme og sidder i slidte sofaer og ser fjernsyn. Hun ved, at mange af dem venter på at kunne se porno, når børnene er kommet i seng. Hun kan lide at tænke på dem, som de sidder der foran tv-apparaterne og ser på de unge kvinder, der stønner og blotter sig for kameraerne. Hun kan lide at gå i gaderne med sine stramme jeans og mærke dem i deres sofaer.

\section{En nabokvinde}

Kvinden snakker, og båndoptageren optager hendes fortælling. Det er allerede længe siden, at det skete, men hun var hendes eneste datter. Man sagde, at kæresten havde skudt en fra de andres gruppe. Kvinden vidste kun, at han pludselig en dag var væk. De kom og hentede hendes eneste datter en sen nat, næsten i morgengryet. Ingen vidste, hvem der gemte sig under hætterne, nogle gættede på politiet. Men snart fandt man hende. Hun var næsten nøgen, havde blod på inderlårene og lå underligt forvredet på jorden lige uden for det område af favelaen, hvor 
kun banditterne kom. Man sagde, at de havde gjort det for at straffe kæresten. Da året var gået, var kvinden på kirkegården, da de åbnede graven. Kisten var næsten hel, den gule kjole var der også, men hendes eneste datter var væk. Kun skelettet var tilbage. Knoglerne blev fjernet, kisten smidt i en bunke, så et andet lig kunne komme i graven. Kvinden snakker, som om hun har fortalt det mange gange før, til alle, som vil høre om hendes smerte.

\section{Uafvendelighed}

Over for huset hænger sære ting i et træ. En plastikdukke uden ben, et toiletsæde, et fuglebur, en støvle, et vædderkranium med store snoede horn. „Den 31.12. er falskhedens dag“" står der malet på et skilt med store penselstrøg. Det hænger og dingler mellem alt det andet. På vejen under træet løber børnene og leger. Jorden er tør efter mange dage uden regn, og bækken, som oversvømmer stuegulvet i regntiden, er næsten tørret ind. Børnene løber barfodede og brune. De ved ikke, at deres brede fødder og brune hud en dag vil bekræfte for verden, at de ikke er noget værd. Solen skærer en virkelighed ud af det mulige. En virkelighed, hvor tiden står stille, og øjne langsomt trættes. Man bliver ved med at komme tilbage til det samme sted. Og hun forstår efterhånden, at sådan vil det være, indtil hun en dag er død.

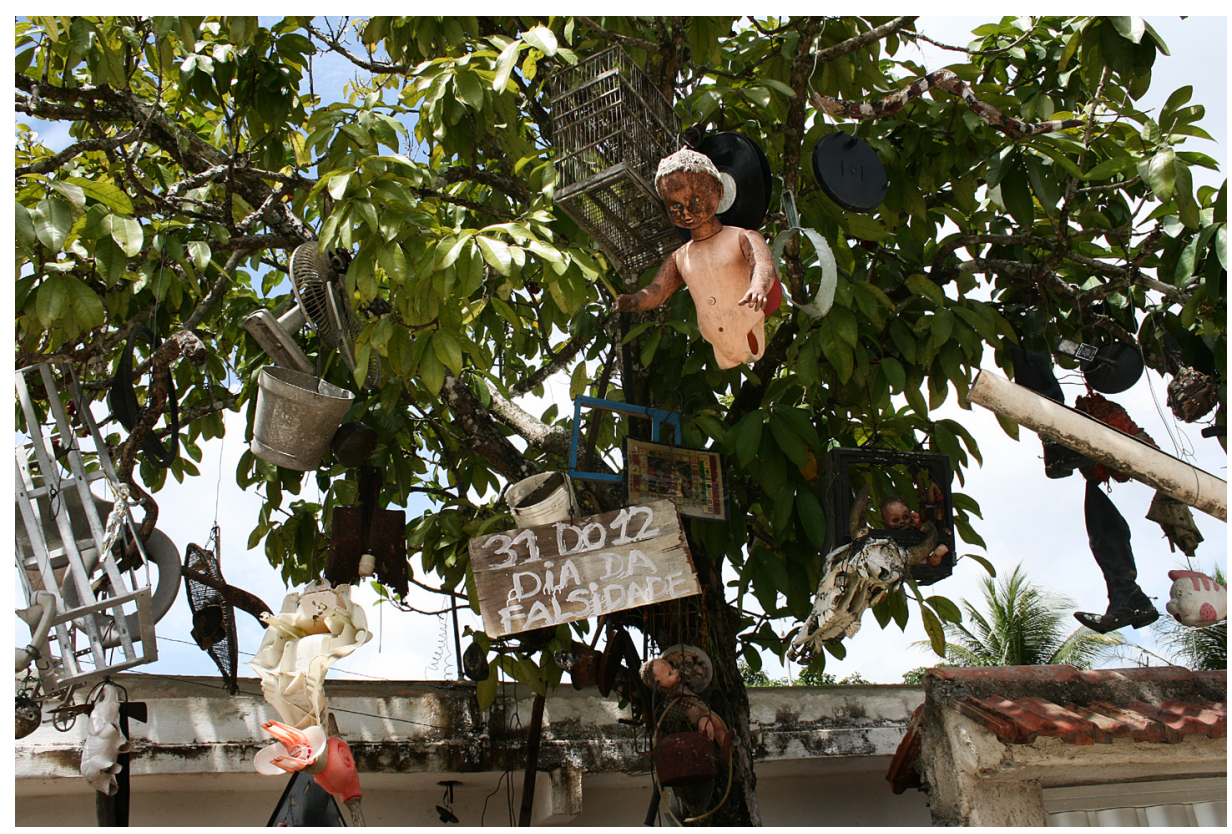

En gal mands værk. Foto: Forfatteren. 


\section{Bendepotet}

Jeg mødte Evinha i 1998, da hun var 18 år gammel. På det tidspunkt boede jeg midlertidigt $i$ hendes nabolag. Jeg var der for at undersøge, hvorfor de fleste kvinder gjorde sig store anstrengelser for at opnå sterilisation (Dalsgaard 2004), og jeg lærte Evinha at kende, fordi hendes mor var en af mine hovedinformanter. Jeg kom ofte i deres hjem og har gjort det mange gange siden, når jeg har været tilbage $\mathrm{i}$ kvarteret $\mathrm{i}$ andet ærinde. Igennem årene med Evinha har jeg båret på et spørgsmål af den slags, der som en uudtalt undren forbliver i baggrunden af tanken, så længe der ikke er grund til at fokusere på det.

Spørgsmålet knytter sig til en eftermiddag, hvor jeg sad med Evinha på hendes seng og forsøgte at få overblik over et materiale, hun havde indsamlet for mig. Hun havde interviewet sin brors venner og nogle af sine jævnaldrende for mig, fordi jeg var interesseret $i$ at vide, hvor mange dræbte mennesker de havde set. Oplevelsen af død og forrådnelse er fremtrædende træk ved livet $\mathrm{i}$ byens fattige kvarterer. Recife er en af de storbyer i Brasilien med procentvis flest dødsfald på grund af vold blandt unge mænd, og ikke bare aviserne er fulde af døde kroppe. At se lig i mere eller mindre forrådnelse er del af hverdagen. Evinha gav mig en lang liste over lig, som de forskellige unge havde set, og det var markant, dels hvor mange de havde set, dels at det var de samme lig, de alle havde set: en kvinde, som var blevet skudt gennem hovedet af sin mand, en fyr, som var blevet bundet til en stol, smidt i en sø og fundet længe efter, en ung fyr på cykel, som var blevet mast af en lastbil, og så alle de mange, som var blevet skudt af rivaliserende eller dominerende narkohandlere. Jeg fandt siden ud af, at ofre for forbrydelser ikke må flyttes, før politiet kommer, besigtiger situationen og tager liget med på Retsmedicinsk Institut. Derfor er der god tid til, at rygtet kan nå rundt, og alle kan nå at se liget. Ofte tager forældre deres børn med, når de selv skal hen og se. Og ofte har politiet pressen med, når de endelig kommer. Derfor er der mange fotos af lig i aviserne.

Evinha var interesseret i samtalen, men skiftede pludselig emne og begyndte at tale om drenge, som så efter hende på vejen og kaldte hende ,galinha“ (kylling), fordi ,de kan lide min krop, den er godt drejet, og de vil have den, og når jeg går forbi med mine bukser sådan [lynlåsen halvt åben], kommer de med kommentarer.“ Og så med ét sagde hun noget lignende: „Men er det ikke mærkeligt, at man gør alt det for at se godt ud, putter creme i håret, på sin krop, bruger minishorts, alt det, bare for en dag at dø, blive glemt og spist af kryb? Åh hvilken smerte!“ Blandingen af begær og død i det, hun sagde, foruroligede mig, og spørgsmålet opstod: Hvordan kunne hun springe så hurtigt fra død og vold til sex - og så lige så pludselig tilbage til død og forrådnelse? 
For nylig talte Evinha igen om død. Hun havde været på kirkegården. Hendes far var død året før, og hans knogler skulle fjernes fra graven. Evinha sagde tilsyneladende ganske upåvirket:

Det er helt normalt, og interessant, man bliver nødt til at tage dem ud, for at en anden krop kan begraves. Jeg troede ikke, jeg ville kunne klare det. En stor, stærk, sort mand, reduceret til bare dét. Et kranium, ribbenene sad stadig sammen, knoglerne i ryggen falder fra hinanden, kisten beklædt med stof, stoffet og hans tøj er der stadig, hans overskæg, han havde næste ikke noget hår til sidst, og gummiet, som de havde brugt ved operationen, alt det var stadig intakt, en pose, der var så lille, en skraldepose, de tømmer det hele ned i en tank. Jeg så hans kranium, lårbensknoglen er ikke så stor, som du tror, alle de små dele i fingrene [...] Men den vigtigste del af ham var der ikke længere [...] Det værste er, at du snart er glemt. Man glemmer, og tiden går - nogen dør, andre bliver født.

Senere, i et andet humør, skrev hun til mig:

Jeg har været til mange begravelser, men den død, som berørte mig mest, var min fars. Han led meget. Jeg ønskede ikke, at hans begravelse skulle være sådan, men mine økonomiske vilkår tillod mig ikke at give ham, hvad jeg gerne ville. Jeg ønskede, at jeg kunne have bevaret resterne af ham, men det kunne jeg ikke. Jeg blev nødt til at se knoglerne blive taget ud og lagt $i$ en plasticpose og siden blive blandet med andre knogler i bendepotet [o depósito de ossos].

Og hun forklarede:

Bendepotet er ligesom en stor cementtank, hvor alle knoglerne bliver smidt, naturligvis knoglerne fra dem, som ikke kan betale for at beholde dem. Kirkegården skulle modtage økonomisk støtte fra kommunen, måske ville det slet ikke være så dyrt. Alle skulle behandles lige. Men hvordan skulle det være muligt? Når vi behandles forskelligt, mens vi er i live, hvordan skulle det så være anderledes efter døden?

Jeg har ikke selv set fremgangsmåden på kirkegården, men Evinha har forklaret det således:

De, som ikke kan betale den månedlige rate, kan ikke selv bestemme, hvor liget bliver lagt. Nogen kommer i jorden, andre i et skab. Graveren skriver bare et nummer for at identificere graven, så man senere kan fjerne knoglerne [og smide dem $\mathrm{i}$ bendepotet]. Efter noget tid brænder de det hele, og det bliver til støv.

Evinhas fortælling fra kirkegården mindede mig om en kvindes beskrivelse af sin datters død, som jeg hørte for nogle år siden. Datteren var blevet voldtaget og myrdet af nogle narkobanditter, som man formodede ville straffe hendes 
kæreste. Imellem de mange detaljer beskrev moderen også, hvordan knoglerne var blevet flyttet efter et år, og hun sagde: „Jeg ved, det var hendes knogler, for jeg så stoffet fra den gule kjole, hun blev begravet med." I begge historier er jeg blevet slået af den nøgternhed, hvormed det hele blev fortalt. Der var noget uafvendeligt ved de to skeletter, stoffet, som havde overlevet kroppen, og nedkastningen i bendepotet.

Da jeg for nylig skulle tale i en sammenhæng, hvor temaet var håb og fremtidsdrømme, kom min undren over Evinhas blanding af sex og død og denne nøgternhed, hvormed skeletterne blev beskrevet, med ét i fokus. Den dag som nu var min påstand, at der er øjeblikke i livet, hvor håb og drømme ikke er mulige, fordi døden i al sin konkrethed ikke lader sig bortforklare. Sådanne øjeblikke opstår, når de fortællinger, som kunne have ladet iagttageren udskyde tanken om endelighed, ikke holder.

\section{Døden i Nordeste}

Begravelser har længe været et spørgsmål om værdighed i Nordeste. I sin bog Death in the Northeast (1966) skriver den brasilianske sociolog Josué de Castro, at det første bondeforbund i regionen, som blev grundlagt i 1955, havde til formål, ikke at forbedre bøndernes leveforhold, men at give dem en værdig begravelse. Fattige bønder blev dengang båret til kirkegården i en kiste udlånt af myndighederne. Men denne kiste fulgte dem kun til kanten af graven, her blev de dumpet i og begravet, hvorefter kisten blev returneret for at blive brugt ved næste dødsfald. Som de Castro formulerer det: „Denne parodi af en ceremoni var den ultimative ydmygelse, en krænkelse, som for bonden syntes at bære helt ind i evigheden. Det første forbund blev dannet for at undslippe denne beskæmmelse“ (1966:12). Forbundet betalte for bøndernes begravelse, og kisten kunne nu følge dem i graven.

I dag har folk fra fattige familier i Recife ret til kommunal hjælp ved begravelse. Man kan fă tilskud til køb af kiste hos en lokal bedemand, men denne rettighed eksisterer ikke uden social ulighed. For få år siden mistede Josenita, hos hvem jeg altid bor, når jeg er kvarteret, sin tante. Josenita er politisk aktiv og stolt over de rettigheder, jævne folk har opnået i Brasilien siden 1980'erne, og således stolt gik hun til bedemanden. Mens hun stod i forretningen for at få den simpleste, billigste kiste til sin tante, kom en kommunalpolitiker ind og brugte sin personlige indflydelse til at udnytte begravelseshjælpen til egen fordel. Josenita græd af harme, da hun fortalte mig om ydmygelsen. Hun kunne kun få en billig kiste på kommunens regning, mens han fik en kvalitetskiste over samme budget. Ydmygelsen bestod ikke i, at tantens kiste var billig, men i at begravelses- 
hjælpen var en rettighed, som burde tilfalde folk ligeligt. Når begravelseshjælpen alligevel blev differentieret, fremstod det, som var ment som rettighed, i stedet som en hån.

I sin bog Death without Weeping beskriver Nancy Scheper-Hughes (1992), hvordan fattige i Bom Jesus, ${ }^{1}$ hvor hun udførte feltarbejde i 1980'erne, ligesom Evinhas far blev begravet eller lagt $i$ et indelukke $i$ et år, hvorefter de blev hentet frem, kisten smidt til side og knoglerne hældt i bendepotet. Folk omkring hende gjorde, hvad de kunne for at undgå en fattig begravelse, for som hun konkluderer, var det den ultimative fattigdom således at forsvinde $i$ anonymiteten på kirkegården: „Måske ingen andre steder vises deres kroppes og livs anonymitet og erstattelighed tydeligere frem for landarbejderne fra Bom Jesus end $i$ den symbolske vold rettet mod deres [jordiske] rester på den kommunale kirkegård, et socialt rum, der som et mikrokosmos reproducerer den sociale og politiske struktur i lokalsamfundet" (op.cit.250). Som Scheper-Hughes også argumenterer, var det ikke bendepotet som sådan, der udgjorde ydmygelsen. Det ydmygende var, at et ordentligt menneske burde kunne betale for sig selv.

I artiklen „Os vivos são sempre e cada vez mais governados pelos mortes“ (De døde er altid, og for hver gang mere, regeret af de døde) (Meneghel, Abbeg $\&$ Bastos 2003) refererer forfatterne til en avisartikel om fattiges begravelser i Porto Alegre, en af Brasiliens rigeste stater. I reportagen beskrives de fattiges del af kirkegården som en plet bar, rød jord, dækket af tusinder af små jernkors identificeret ved nummerplader, uden navn. Stedet ligner en krigskirkegård. En far, som begraver sit døde barn på kirkegården, siger: „Der er ikke noget tristere end de fattiges begravelse, for de fattige begynder allerede, mens de er i live, at blive begravet" (op.cit.). Som forfatterne skriver, gør det ikke ydmygelsen mindre, at fattige begraves med næsten samme ligegyldighed fra myndighedernes side som i slaveriets tid. Samfundet har forandret sig væsentligt, men en del af befolkningen (i Porto Alegre en mindre del end i Nordøstbrasilien) fastholdes $i$ et mønster, som burde høre fortiden til: „Det er en flad [ikke-dyb] grav for at gøre det nemt at tage liget op efter de tre år [koldere klima end Recife], en doneret kiste og en kirkegård på en skråning, og dette er efterhånden foregået i mere end 500 år" (Meneghel Abbeg \& Bastos 2003:693).

Ideen om døden som den endelige fastsættelse af en persons værdi er ifølge Thomas Laqueur (1983) en historisk konstruktion. Fattige er altid blevet begravet med mindre pomp og pragt end rige, men i og med det borgerlige samfund blev en ordentlig begravelse indbegrebet af en persons sociale værdi. Fordi social status ikke længere kun blev tildelt ved fødslen, men kunne optjenes gennem et stræbsomt liv, kendte ingen en persons fulde værdi, før han eller hun var død. Derfor blev begravelserne i det borgerlige samfund ritualer, der markerede 
den enkeltes sociale plads, hvor de tidligere primært havde adresseret det fællesskab, den døde havde været del af. Med dette skift blev en begravelse et forbrugsgode (op.cit.114). Som Laqueur skriver: „Da begravelsen således blev det endegyldige bevis på en død mands renommé blandt hans fæller, kom ceremonien i byen og i stigende omfang også på landet til at repræsentere den dødes løsrivelse fra de organiske bånd til fællesskabet og begravelsespladsen blev endnu en virkelighed, der kunne købes og sælges for penge“" (op.cit.115).

På kirkegården, hvor Evinhas far ligger begravet, betaler man som nævnt for en plads. Derudover betaler man bedemanden for selve begravelsen. Bedemænd udstiller deres varer helt ud på fortovet, og der er stor forskel på de priser, kister forhandles til. Hos en lokal bedemand kan man købe en begravelsesplan til 35 reais om måneden (en real $=$ ca. $3 \mathrm{kr}$.). Den giver ret til en kiste af middel standard, blomster og lys til vågenatten. Uden en sådan begravelsesplan koster den billigste kiste 780 reais, blomster skal købes derudover, og man kan ikke lade liget opbevare hos bedemanden. Hos en anden lokal bedemand koster en begravelsesplan 25 reais ved oprettelsen og 20 reais om måneden. Den dækker seks personer, som har ret til kiste med rude, blomster og lys. Den billigste kiste koster 650 reais, men man kan også købe til 6500 og 8000 reais. Den sidste type kiste har et låg helt af glas. Evinhas far blev begravet i den billigste kiste og med få blomster. Man havde lagt papir under blomsterne, så de skulle se ud af mere. Som Evinhas mand senere så pragmatisk sagde: Hvorfor smide penge ud på pynt og kiste, når det hele alligevel bliver til ingenting.

De unge fra kvarteret anser det for ret og rimeligt, at man skal betale for kiste, blomster og andet udstyr, og at der derfor må være forskelle i folks formåen. Som med alt andet i Brasilien, siger de, er der forskel på fattig og rig. På kirkegården sker der imidlertid et markant brud, hvor det ikke længere er et spørgsmål om gradsforskelle, men om enten-eller. Nogen kan fortsat eksistere som individer, mens andre forsvinder, først ved at blive lagt $i$ en grav uden navn, kun med et nummer, siden ved at blive smidt på bendepotet. Det vigtige er her, at reglen (i bourdieusk forstand), som Evinha refererer til, er at beholde knoglerne i en navngivet familiegrav, og i forbindelse med sin fars død beklagede Evinha, at hun ikke kunne gøre det. For Scheper-Hughes' informanter var den fattiges begravelse en skam, som måtte undgås, hvis man kunne, og undgås måtte også påmindelsen om den. Fattige i Bom Jesus gik derfor ikke på kirkegården på allehelgensdag den 2. november, som bedrestillede borgere gjorde. De have intet at komme der for, ingen gravmonumenter, ingen lys, som skulle tændes: „Den lokale kirkegård [...] er et sted, der skal undgås. Den står som en kraftig påmindelse om de fattiges skrøbelige ikke-eksistens, deres socialt konstituerede væren og intethed“", skriver Scheper-Hughes (1992:258). 
Hverken af mine egne data eller af Scheper-Hughes' fremgår det direkte, at bendepotet er en oplevelse af egen intethed og endelighed. Visse ting i livet lader sig sjældent italesætte, men skal udledes af fortielser og antydninger. Det er nøgternhed, som står tilbage, når jeg har hørt tale om bendepotet, som var det blot en kendsgerning. Min påstand er dog, at det er en ganske særlig hård kendsgerning, fordi den så endegyldigt demonstrerer den fattiges uformåen i forhold til at blive „nogen i livet“, som folk i Evinhas kvarter udtrykker det. Ikke kun den dødes manglende opsparing af tilstrækkelig social og økonomisk kapital igennem livet, men også hans slægtninges, som i det afgørende øjeblik ikke er i stand til at betale for en navngiven grav. Bendepotet er et fait accompli, der udfordrer beskuerens følelse af handlekraft og stiller spørgsmål til fremtiden, for hvordan vil det familiemedlem, som ikke kan betale for at bevare sin slægtnings jordiske rester, selv ende sine dage? En dag er kun knoglerne tilbage, og nogen vil blive nødt til at smide dem i bendepotet. Skelettet er som en fremtid, der ser på nutiden, og i dette blik fra fremtiden træder individet ikke længere frem som subjekt, men som objekt for andres handling.

\section{Tilblivelse i blikket}

Ifølge Maurice Merleau-Ponty oplever vi ikke os selv som afgrænsede individer fra fødslen. Vi er fra begyndelsen kastet ind i verden, og erfaringen af adskillelse og individualitet er sekundær. I løbet af barnets første leveår begynder det at opleve sig selv som set udefra, adskilt fra forældre som kan gå, og ting som kan blive væk, og hermed opstår et ,ideelt, fiktivt eller forestillet mig“(MerleauPonty 1968:136). Dette forestillede ,mig“, forestillingen om, hvordan ,mig“"ser ud i andres perspektiv, indebærer en fremmedgørelse over for den umiddelbare oplevelse, individet kan have af sig selv. Ifølge George Herbert Mead er dette dog ikke en proces uden mulighed for refleksion, da der mellem, ,jeg“ og ,,mig“ er indskudt en forsinkelse. ,Jeget“" er ,mig'et“ for et øjeblik siden, fordi „mig'et“ er en objektivering eller opsamling af erfaring (Mead 1965:174). „Jeget“ er et potentiale, som ligger uden for vores umiddelbare fremtræden (op.cit.204), og som Nick Crossley foreslår, kan man sammenligne ,jeget“ hos Mead med „,det merleau-pontyske kropsubjekt: perciperende og aktivt, men endnu ikke refleksivt opmærksomt på sig selv“" (1996:55). Denne begrebsramme fremstiller således selvbevidstheden som uvægerligt forsinket i forhold til jeget, der som en ukendt individualitet stræber efter at blive kendt (af sig selv) gennem andres anerkendelse.

Spaltningen indebærer potentielt en oplevelse af fremmedgørelse, idet man ikke oplever at bebo sit selv, men modtager det fra andre (Merleau-Ponty 1968: 
136). Fremmedgørelse opleves ikke nødvendigvis negativt, da det at være „nogen" $i$ andres blik kan føre til stolthed, selvrespekt og værdighed. Men i det øjeblik, vi ikke føler, vi har indflydelse på blikket, som ser os, og vores handlinger og udtryk ikke modtages og forstås af andre i indbyrdes respekt, men bliver „observeret, som var de et insekts“" (Merleau-Ponty i Crossley 1993:415), da kan blikket udefra opleves som en trussel. Som Crossley skriver, vil subjektet føle sig reduceret til et objekt $i$ andres verden, hvis det føler, at det ikke kan kontrollere sit ydre billede og selv definere betydningen af sine handlinger (Crossley 1996:61).

I en kommentar til Sartres Being and Nothingness (1956) understreger Michael Jackson (1998:17), at oplevelsen af intethed opstår, når man føler sig ude af stand til at gøre eller sige noget, som kan ændre andres definition af situationen og dermed af en selv (op.cit.17). At være er at kunne vælge, og ikke-væren, intethed, er følgelig ikke at have et valg. Eller som han selv præciserer det: „Intethed er ikke så meget et fravær af mening, en metafysisk mangel, et intellektuelt tomrum, en oplevelse af at være ubetydelig. Intethed opstår af en manglende mulighed for at handle“ (ibid.). Derfor, skriver Jackson, indeholder ethvert menneskeligt møde risikoen for at føle sig reduceret til intethed, objektiveret som en genstand $i$ andres verden.

Jeg har tidligere beskrevet, hvordan fattige i Recife oplever at blive behandlet som andenklasses borgere i konkrete møder med bedrestillede folk, for eksempel sundheds- og butikspersonale, og hvordan de føler sig mindreværdige under „blikket“" fra middelklassenormer, som udtrykkes i tv eller i kampagner til fremme af sundhed, børns rettigheder og børneopdragelse (Dalsgaard 2004). Jeg har i den forbindelse refereret William James' ofte benyttede passage: „Hvis ingen vendte sig, når vi kom ind, svarede, når vi talte, eller lagde mærke til, hvad vi gjorde, men hvis hver person, vi mødte, 'cut us dead' og opførte sig, som var vi ikke-eksisterende ting, ville en slags raseri eller afmægtig desperation snart vælde op i os, over for hvilken selv den ondeste kropslige tortur kun ville være en lettelse. For uanset hvor hård en knibe vi måtte være i, ville den lade os føle, at vi endnu ikke var sunket så dybt, at vi var uværdige til opmærksomhed overhovedet" (James 1950:293). Mindreværd i dagligdagen kan ofte modvejes af indignation og latter (Goldstein 2003), men man skal ikke dvæle længe ved tanken om bendepotet, før nedkastningen deri står frem som den ultimative, uafrystelige ignorering af menneskeligt værd, en demonstrativ overgang fra væren til ikke-eksisterende ting. Det er imidlertid ikke, fordi fattige også her behandles med mindre respekt end bedrestillede, at bendepotet er så brutalt, men fordi den manglende respekt stiller fattige uden beskyttelse over for dødens endegyldige faktum. ${ }^{2}$ 


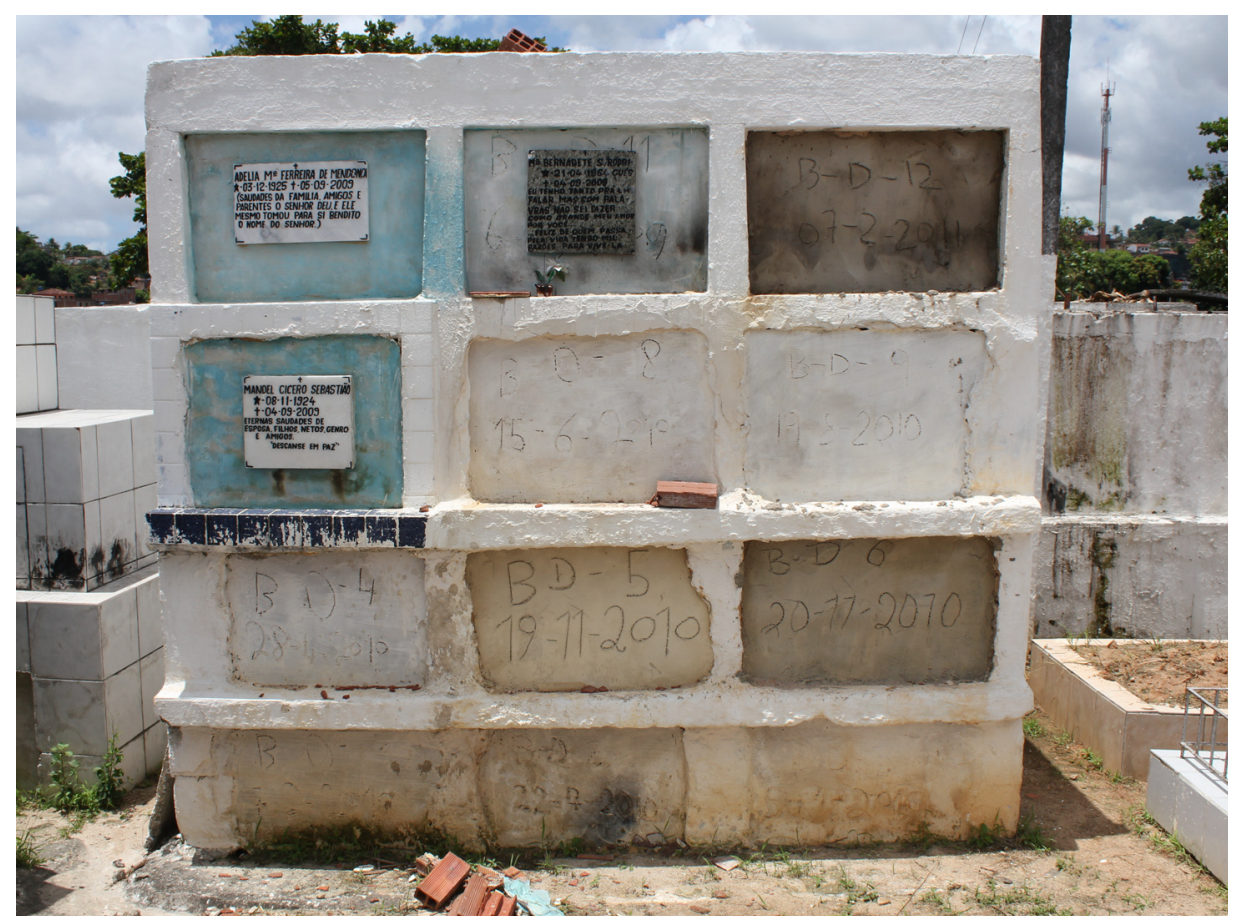

Indelukkerne, en slags skabe i en mur, hvor fattiges kister lægges et år. Foto: Forfatteren.

\section{Død, tid og sex}

I Mortality, Immortality and Other Life Strategies (1992) argumenterer Zygmunt Bauman for, at døden ikke er som andre ,andre“, over for hvilke egoet kan forhandle sin position og forsøge at opnå anerkendelse. Døden er ,den absolutte værensanden, en ikke-tænkelig anden, ude af rækkevidde for kommunikation“, det vil sige en ,anden“, man kun kan tale om som negation, fravær, ophør af eksistens, og da alligevel slet ikke (op.cit.2). Bauman skriver videre, at andres død derfor ikke er som ens egen død. Andres død stopper ikke ens egen fortløbende perception. Netop derfor er den så rystende: ,Jeg frygter måske andres død mere end min egen. Jeg råber måske med stor oprigtighed, at jeg hellere selv ville $\mathrm{d} \varnothing$ end opleve en elsket andens død - men dette er præcis på grund af min viden om, at efter denne død ville jeg blive nødt til at stå over for et særligt ingenting, et tomrum, som den dødes afsked ville skabe, et tomrum, som jeg ikke ønsker at opleve, men som stædigt og til min rædsel er fuldt og klart opleveligt“" (op.cit.3). Tomrummet, som opstår ved en elsket persons død, skyldes ikke kun fraværet af denne person i tiden, som skal komme, men selve det faktum, at stillet over for døden er det meste af det, vi normalt stræber efter, ikke længere interessant. 
Interessen for ,spillet“, illusio, er ifølge Bourdieu det, som driver os ind i endeløse kampe om anerkendelse, hvor det til stadighed drejer sig om at opnå social væren („kapital“ i Bourdieus terminologi). Tid opstår i det øjeblik, vi interesserer os for spillet, skriver Bourdieu (2000:207), idet illusionen (eller interessen for spillet) er det, som giver mening (både betydning og retning) til livet ved at lede os til at investere i spillet og det, som forventes at komme deraf. Man kastes frem i tiden i den retning, spillet angiver, mod det, som vil komme, fuld af in-order-tomotiver (Schutz \& Luckmann 1973:212). „Vores livsverden er karakteriseret af en praktisk, fremtidsorienteret og instrumentel måde at være i verden“, skriver Bourdieu (2000:123), og i denne fremadrettethed lever vi uden opmærksomhed på vores krop som materielt nærvær i nuet (Leder 1990). Subjektet bliver derved i dybeste forstand tid, idet det er subjektet. som kan opleve, at fremtid (og fortid) eksisterer. Det er kun set fra subjektets nutid, at noget var „før“, og at andet skal komme. Illusionen, som driver os fremad mod det, som skal komme, kan imidlertid bryde sammen. Stillet over for sammenbruddet giver verden ikke længere mening.

Mit argument er, at den objektivering af subjektet (og derved ophør af tidens udstrækning), som skelettets nedkastning i bendepotet repræsenterer, kun kan balanceres af noget tilsvarende objektiverende og om ikke illusionsnedbrydende, så øjebliksrettet. I sin artikel „Objectification“(1995) definerer Martha Nussbaum objektivering som det at behandle noget, som ikke er en ting, men et menneske, som en ting. Vores omgang med ting er ifølge Nussbaum karakteriseret ved aspekter af instrumentalitet (tingen er et redskab defineret af den handlendes formål), benægtelse af autonomi (tingen har ingen selvbestemmelse), passivitet (tingen har ingen handlekraft), udskiftelighed (andre ting af samme slags kan erstatte tingen), ødelæggelighed (tingen kan splittes ad), ejerskab (tingen kan ejes, købes og sælges) og benægtelse af subjektivitet (objektets oplevelser og følelser, hvis de overhovedet eksisterer, er irrelevante) (op.cit.257). At objektivere betyder at behandle et menneske på en eller flere af disse måder. For som Nussbaum understreger: at behandle ting som objekter er ikke objektivering. Objektivering består $i$ at behandle menneskelig væren som menneskelig ikke-væren, det vil sige som en ting.

Ifølge Jackson er forholdet mellem væren og ikke-væren ikke absolut, men et spørgsmål om en vedvarende forhandling eller balancering, som han skriver, af graden af subjektets indflydelse på verden (1998:18). Det er en balancering af forholdet mellem det, som er givet, og det, som er valgt (op.cit.21). Denne søgen efter subjektiv kontrol over forholdet til omverdenen er ikke nødvendigvis erkendt. Snarere kan man sige, at verden har magt over os, netop fordi vi ikke erkender vores engagement i den. På et vist plan kan vi dog gøre rede for for ek- 
sempel de individuelle forsøg, vi gør for at ændre andres opfattelse af os, og vi kan give udtryk for følelser af modløshed og mindreværd i andres øjne. Der er imidlertid oplevelser af givethed, som ikke umiddelbart lader sig adressere $i$ tale eller handling, og over for hvilke vi står næsten lige så illusionsløse som over for døden. Sex kan udgøre en sådan oplevelse. Når jeg i det følgende argumenterer for dette, tilsidesætter jeg for en stund det argument, at sex, begær og flirt naturligvis også kan veckke illusioner og bruges i en stræben efter position og magt. Der er, vil jeg mene, både en strategisk og en eksistentiel side af sex, og her er det sidstnævnte, jeg refererer til.

Evinha er interesseret i porno og har været det så længe, jeg har kendt hende. Hun var i begyndelsen af tyverne, da hun ville have mig til at tage et billede af sig i bikini og højhælede sko, som hun ville lægge ud på en pornowebside, og mens vi talte om det, fortalte hun mig om de pornoprogrammer, hun plejede at se. Porno sendes jævnligt på brasiliansk tv, og Evinha plejede at se pornoprogrammer sammen med sin bror, far eller alene. Nu er hun flyttet hjemmefra og bor sammen med en mand, hun holder af. Sidst jeg besøgte hende, fortalte hun mig om analsex, om, hvor godt det var, og hvordan hun havde pjattet med det sammen med pigerne i butikken, hvor hun på det tidspunkt arbejdede. „Åh, det er så godt, Lini, men du skal ikke få for meget numse [bunda], for så bliver din mund sådan her." Hun viste mig sin rundede mund, og hvordan hun ville trække vejret stødvist og tungt, som skulle hun udholde fysisk smerte, og lo højt.

Evinha har tit udfordret mit eget mere bornerte forhold til sex ved så udpræget at fremhæve det kødelige og tingslige i den seksuelle handling. Men netop i det kødelige og tingslige ligger måske svaret på mit spørgsmål fra hin dag, da Evinhas associationer sprang fra død til sex og tilbage til død igen. Det er oplevelsen af kroppens materialitet og fremtidens irrelevans, som binder dem sammen. Den erotiske forståelse er en umiddelbar forståelse gennem kroppen: „Begæret forstår blindt ved at forbinde krop med krop“ (Merleau-Ponty 1962:130). Samtidig er der noget dybt ubegribeligt ved den seksuelle erfaring, som har med dens nufokusering at gøre (Karlsson 2010:130). I den seksuelle oplevelse mister fremtiden sin relevans. Ganske vist kan begæret rettes frem mod noget, som endnu ikke er, men dette ,noget“ er kun opfyldelsen af begæret og dermed fraværet af det: „Der er ingen anden intention end at opnå tilfredsstillelse, så trangen og trykket kan ophøre" (op.cit.135). Der er samtidig i denne intention et træk imod det ukendte, imod sammensmeltningen af kroppe og forløsning ved en kraft, man ikke selv behersker, som står i stærk kontrast til vores normale krops- og virkelighedsopfattelse (op.cit.137). Det er den direkte forståelse mellem kroppe, fremtidens irrelevans og denne overskridelse af det kendte og overgivelse til det ukendte, som gør sex til en særlig kraft i vores liv. 
Overgivelsen til det ukendte kan imidlertid også indebære en overgivelse til en andens definition af situationen, i hvilken man selv bliver objekt for dennes handlinger. Porno anses ofte for at udgøre en dehumanisering af kvinder, en kritisabel objektivering af dem som ting eller varer, sat i verden for at tilfredsstille andres begær (Nussbaum 1995:249). Men ikke al overgivelse af sig selv til en anden som objekt (kønsorgan, bryster, baller, mund etc.) er trods desubjektiveringen nedværdigende. Som Martha Nussbaum skriver, kan seksuel objektivering - også for den umiddelbart objektiverede - i nogle sammenhænge være både nydelsesog meningsfuld, hvis ikke ligefrem nødvendig: „I spørgsmålet om objektivering er kontekst alt" (op.cit.271). Mit indtryk er, at for Evinha er det afgørende, at hun oplever selv at vælge. ${ }^{3}$

\section{Gaven}

Over årene med Evinha har jeg aldrig forstået hendes næsten insisterende trang til at være objekt for mænds begær. Hendes udfordrende tøj, opmærksomheden på de mænd, hun passerede, den lettere ophidsede snak om de fyre, hun havde været sammen med - jeg har mest været irriteret over afbrydelserne, det skabte, i de samtaler, jeg fandt vigtigere. Mændene, hun har været sammen med, har altid været unge som hende selv, men at gå med Evinha på gaden har lært mig, at hun kan lide at blive set som seksuelt objekt af hvem som helst. Hun er langtfra den eneste, som klæder sig smart og ordner håret, før hun går en runde i kvarteret hen under aften. Brasilien er et sted, hvor kvinders seksuelle værdi generelt er i fokus, og især unge kvinder er sig denne værdi meget bevidst. Hun er heller ikke den eneste, som er så udfordrende og fræk. Der er andre, ofte mørke i huden som Evinha, der på samme pågående måde spiller deres erotiske kapital (Hakim 2010) ud. Faktisk er det måske netop mørke kvinder, som gør det, fordi de ikke som lysere kvinder udgør attraktive ægteskabspartnere (Goldstein 1999:564; Dalsgaard 2004:72; Petruccelli 201). Når jeg alligevel holder mig til argumentet om Evinha, er det, fordi jeg bevæger mig på grænsen til gætværk og vil afprøve min påstand på et felt, en person, jeg kender godt.

Det er nemlig nu muligt at spørge, om det ikke netop er Evinhas overgivelse til den seksuelle objektivering, som balancerer den intethed, nedkastningen i bendepotet (og andre konfrontationer med dødens konkrethed) må repræsentere. I accepten af den seksuelle objektivering giver hun sig bort som objekt for mændene, som en gave. Lige siden Marcel Mauss har vi vidst, at en gave aldrig er ganske fri af den person, som giver den, og at modtageren derved sættes i gæld. Så længe gaven ikke gengældes, har giveren et overtag. Men hvem er modtageren af Evinhas gave? Med hvem indgår hun en udveksling, når hun har sex med en 
fyr en mørk nat bag en husmur, når hun lader sig beglo af de midaldrende mænd, som spiller domino i skumringen, eller når hendes nuværende mand tager hende bagfra? Mændene har fornøjelse af hendes krop, selv de, som bare ser, men fordi den erotiske oplevelse også overskrider kroppens grænser i en bevægelse mod det ukendte, er det ikke kun med de konkrete mænd, at udvekslingen sker. Mændene er også kanal for en gavegivning, der adresserer et punkt hinsides hverdagserfaringen. Det punkt, hvorfra det udslettende blik kommer.

Med andre ord vil jeg påstå, at visse brutale kendsgerninger må balanceres på det oplevelsesplan, hvor ting bare er, og hvor intet „Hvad nu hvis ...?“er relevant. Oplevelsen af intethed, som blikket fra skelettet foranstalter, må således balanceres af en handling på samme eksistentielle niveau, det vil sige på et niveau, hvor kropsligheden med dens nufokusering dominerer, og hvor for et øjeblik hverken drømme, håb eller fortællinger kan omdefinere det givne til noget valgt (Jackson 1998:23-4). På dette plan af givethed adresserer den seksuelle objektivering kroppen som et objekt for andres handlen, ligesom bendepotet markerer subjektets mangel på handlekraft og kroppens udskiftelighed. Men samtidig er der i den seksuelle objektivering (såfremt den finder sted uden tvang) en hengivelse, som udgør et aktivt valg. På gode dage trumfer dette valg døden

\section{Epilog}

„Den 31.12. er falskhedens dag“" står der på en plade ophængt i et træ i kvarteret. Folk går forbi og tænker: „Det er en gal mands værk.“ Men ved eftertanke ved de, at han har ret. Forhåbningerne til det nye år gøres som regel til skamme af dagene, som kommer. Får man det lidt bedre en stund, ved man samtidig, at de hårde tider nok skal komme tilbage. Der er ikke megen fremgang uden lige så mange tilbageskridt. Evinha tænker ikke for meget på det. Hun nyder sin krop. Svanser, går i minishorts, mærker lysten hos sig selv og mændene. Blodet dunker, og hun ler højt. Der er mange, som synes, hun er for udfordrende. At hun burde tænke mere på sin fremtid. Studere. Hun er ligeglad og har anskaffet sig en pitbullterrier. Den er farlig, det ved hun. Kan til enhver tid angribe. Men det er hendes, hun har givet den navn. Hun balancerer på en knivsæg og ved, at hun er i live. 


\section{Noter}

Tak til ph.d.-studerende Marie Bræmer og to anonyme fagfæller for kritisk læsning og gode råd.

Alle citater i denne tekst er taget fra engelske tekster og af mig, efter bedste evne, oversat til dansk. Artiklen er skrevet i forbindelse med projektet „Med fremtiden som handlerum“, der er et komparativt projekt, som fokuserer på socialt marginaliserede unges orientering mod fremtiden. Projektet er støttet af Det Frie Forskningsråd (FKK).

1. Bom Jesus er et dæknavn for den by, Scheper-Hughes arbejdede i, først som Peace Corps-medarbejder i 1960'erne og siden som antropolog i 80'erne. Byen ligger ifølge hendes angivelser ca. $60 \mathrm{~km}$ fra Recife.

2. Jeg er klar over, at dette udsagn for argumentets skyld forsimpler situationen. Der er naturligvis andre måder at holde endeligheden på afstand på end ved at gemme en elsket persons jordiske rester på en kirkegård. Man kan hænge et billede på væggen, man kan fortælle historier, man kan tale med den afdødes ånd, eller den døde kan før sin død have lavet en cd-rom med billeder og tekst om sig selv, som familie og venner siden kan bevare som minde (en strategi, Evinha selv har tænkt at benytte). Men samtidig må jeg sige, at der hænger meget få billeder af slægtninge på væggene i kvarteret, der er meget sjældent snak om afdøde slægtninge (mest mødres sorg over døde børn), og der er generelt en mangel på historisk dybde i folks fortællinger, som synes at hænge sammen med en forventning om tab. Scheper-Hughes bemærkede i Death Without Weeping (1992), at de fattige beboere i Bom Jesus ikke benyttede efternavne. Det samme gør sig til dels gældende i kvarteret, hvor jeg arbejder. Det er ikke ualmindeligt, at unge mennesker ikke kender deres forældres efternavn. Fattige familier bærer desuden ofte navne som da Silva (fra skoven) og do Nascimento (fra fødslen), efternavne, som er givet til slaverne i sin tid ved deres frigivelse (op.cit.91). At være del af en navngivet slægt er ikke et privilegium, som tilfalder fattige folk.

3. Jeg er klar over, at spørgsmålet om valg her kan føre til en længere diskussion. For Evinha er der ikke mange andre måder at overleve på, for hende selv og barnet, end at blive forsørget af en mand. Hun er derfor, i et andet analytisk perspektiv end det, som her har interesseret mig, underlagt kulturelle (machistiske) normer, som giver hende meget lille råderum. Som Nussbaum skriver, er det svært at definere forholdet mellem seksuelt begær og de økonomiske normer og motiver, som magtfuldt fremmer centrale former for begær i samfundet (Nussbaum 1995: 290).

Søgeord: fattigdom, død, fremtid, objektivering, sex, Brasilien

\section{Litteratur}

Bauman, Zygmunt

1992 Mortality, Immortality and Other Life Strategies. Oxford: Polity Press.

Bourdieu, Pierre

$2000 \quad$ Pascalian Meditations. Stanford, CA: Stanford University Press.

Castro, Josué de

1966 Death in the Northeast. New York: Random House.

Crossley, Nick

1993 The Politics of the Gaze: Between Foucault and Merleau-Ponty. Human Studies 16:399-419.

1996 Intersubjectivity. The Fabric of Social Becoming. London: Sage Publications Ltd. 
Dalsgaard, Anne Line

2004 Matters of Life and Longing. Female Sterilisation in Northeast Brazil. København:

Heidegger, Martin Museum Tusculanum Press.

2001 [1927] Væren og tid. Århus: Forlaget Klim.

Goldstein, Donna

1999 "Interracial" Sex and Racial Democracy in Brazil: Twin Concepts? American Anthropologist 101(3):563-78.

2003 Laughter Out of Place. Race, Class, Violence, and Sexuality in a Rio Shantytown. Berkeley: University of California.

Hakim, Catherine

2010 Erotic Capital. European Sociological Review 26(5):499-518.

Jackson, Michael

1998 Minima Ethnographica. Intersubjectivity and the Anthropological Project.

Chicago: University of Chicago Press.

Karlsson, Gunnar

2010 Psychoanalysis in a New Light. Cambridge: Cambridge University Press.

Laqueur, Thomas

1983 Bodies, Death, and Pauper Funerals. Representations 1(1):109-31.

Mead, George Herbert

1965 [1934] Mind, Self and Society. Chicago: The University of Chicago Press.

Meneghel, Stella N., Claídes Abbeg \& Ronaldo Bastos

2003 Os vivos são sempre a cada vez mais governados pelos mortos: um estudo exploratório sobre desigaldade no morrer. Historía, Ciências, Saude 10(2): 683-702.

Merlau-Ponty, Maurice

1968 The Primacy of Perception and Other Essays. Evanston, IL: Northwestern University Press.

Nussbaum, Martha C.

1995 Objectification. Philosophy and Public Affairs 24(4):249-91.

Petruccelli, José Luis

2001 Seletividade por Cor e Escolhas Conjugais no Brasil dos 90. Estudos AfroAsiáticos 23(1):29-51.

Scheper-Hughes, Nancy

1992 Death Without Weeping. The Violence of Everyday Life in Brazil. Berkeley:

University of California Press.

Schutz, Alfred \& Thomas Luckmann

1973 The Structures of the Life-world. London: Heinemann.

1998 The Reproductive Health of Brazilian Women During the "Lost Decade".

I: G. Martine, M.D. Gupta \& L.C. Chen (eds.): Reproductive Change in India and Brazil. Delhi: Oxford University Press. 